DOI: https://doi.org/10.30525/978-9934-26-108-4-2

Nadiya Kazakova

PhD of Geographical Sciences, Associate Professor, Head of Artur Golikov International

Economic Relations Department

V.N. Karazin Kharkiv National University

Olha Maiboroda

PhD of Economic Sciences, Associate Professor, Associate Professor of Artur Golikov International

Economic Relations Department

V.N. Karazin Kharkiv National University

\title{
INTERNATIONAL LOGISTICS ACTIVITY: MAIN TRENDS AND INFORMATION TECHNOLOGIES IN A PANDEMIC CONDITION
}

\section{Summary}

The current stage of the development of society is characterized by the growing role of information technology. They actively influence the state of political, economic, defense, and other components of state security. The diversity of information technologies creates a need to develop theoretical and empirical classifications of technologies in logistics. The main tendencies of logistics activity at the world level are considered in the work, having considered the rating Logistics Performance Index. Germany as a leading country is singled out and the main factors influencing the development of logistics in this country are considered.

The advantages and disadvantages of the main modes of transport that provide logistics are highlighted and the negative consequences of the pandemic are investigated. Examples of overcoming the consequences of a pandemic in the logistics activities of individual countries are given.

\section{Вступ}

Міжнародна логістична діяльність - це одна 3 найчастіше обговорюваних сфер міжнародної торгівлі, адже економічний складник сьогодення цілком та повністю знаходиться під впливом міжнародних процесів. Глобалізаційні тренди світової торгівлі потребують зростання обсягів логістичної діяльності, зокрема поліпшення інформаційних потоків задля більшої ефективності роботи усіх наявних систем.

Поєднання технологій та інновацій змінює транспортний бізнес та логістику таким чином, що має вирішальне значення для вдосконалення існуючих процесів. Логістична галузь переживає час швидких i безпрецедентних трансформацій. Майбутнє логістики насичено 
інноваціями та технологіями. Сьогодні галузь обережно застосовує ці технології, щоб забезпечити швидшу, дешевшу, надійнішу та стійкішу доставку. Нові технології в ланцюжку поставок можуть допомогти підвищити його гнучкість, ефективність роботи, скоротити час циклу, досягти більш високої ефективності і доставки товару клієнту вчасно. Інтеграція інформаційних технологій в існуючі операції може багато в чому допомогти в поліпшенні обслуговування клієнтів, скороченні витрат та оптимізації ланцюжків постачань.

На ефективність і успішність бізнесу безпосередньо впливає швидкість обробки замовлень та отримання необхідних відомостей. Зростаючий обсяг інформаційних потоків, що піддаються обробці, робить упровадження інформаційних технологій у різні сфери життя сучасного суспільства необхідним і неминучим. Особливого загострення це набуло в останні два роки під дією низки жорстких обмежень, пов'язаних із пандемією COVID-19, коли було зруйновано роками налагоджені логістичні ланцюги та підприємствам потрібно підлаштовуватися під виклики сьогодення.

\section{Розділ 1. Головні тенденції міжнародної логістичної діяльності}

Ефективний розвиток економіки будь-якої держави залежить від різних чинників, один $з$ яких - успішна робота транспортної галузі. Підприємства, які надають послуги з транспортування, та логістичні компанії - сьогодні це обов'язковий складник комунікацій на внутрішньому рівні країни та забезпечення торгівлі на зовнішніх ринках. Важливим складником успішного функціонування міжнародної логістики $є$ налагоджена система транспортування вантажу, яка надає можливості збільшити загальну ефективність логістичного процесу, максимально знизити операційні витрати та підвищити якість логістичних послуг.

Створення логістичної системи у вигляді системи зі зворотними зв'язками $є$ достатньо довгим процесом, потребує чіткої організації та викликає постійний інтерес до дослідження логістичних об'єктів. Найбільший інтерес як об'єкта для розгляду на сучасному етапі $\epsilon$ логістичні моделі країн - лідерів рейтингу за індексом LPI (Logistics Performance Index) [1; 2].

Індекс ефективності логістики відноситься до одного із таких методів, який досліджує ефективність логістики у різних країнах (табл. 1).

Отже, приведені дані країн за індексом розвитку логістики 2012-2018 pp. показують достатньо жваву динаміку. Серед країн, які значно поліпшили за цей період своє рейтингове місце, слід виділити Австрію (+8 позицій), Швецію $(+11)$ та Бельгію $(+4)$. Водночас найбільше свої позиції погіршили Фінляндія (-7), Данія (-2), Сінгапур (-6), Канада (-6) та США (-5). Лідером рейтингу залишається Німеччина. 
Визначивши головних учасників рейтингу, перейдемо до феномену Німеччини - чому ж вона майже завжди на першому місці. Для цього потрібно роздивитися детальніше кількість державних інвестицій у транспортну інфраструктуру, а саме у залізничний, автомобільний та авіатранспорт (рис. 1).

Саме завдяки цьому транспортна система Німеччини настільки розвинута, комплексна та модернізована. Також потрібно відзначити, що система $є$ такою й завдяки тому, що країна знаходиться у самому центрі Європи, а отже, транспортна система забезпечує не лише перевезення по Німеччині, а також і транзитні перевезення.

Таблиця 1

Індекс ефективності логістики, 2012-2018 рр.

\begin{tabular}{|c|c|c|c|c|c|c|c|c|}
\hline \multirow[b]{2}{*}{ Держава } & \multicolumn{2}{|c|}{2012} & \multicolumn{2}{|c|}{2014} & \multicolumn{2}{|c|}{2016} & \multicolumn{2}{|c|}{2018} \\
\hline & $\begin{array}{c}\text { LPI } \\
\text { показ- } \\
\text { ник }\end{array}$ & $\begin{array}{c}\text { LPI } \\
\text { місце }\end{array}$ & $\begin{array}{c}\text { LPI } \\
\text { показ- } \\
\text { ник }\end{array}$ & $\begin{array}{c}\text { LPI } \\
\text { місце }\end{array}$ & $\begin{array}{c}\text { LPI } \\
\text { показ- } \\
\text { ник }\end{array}$ & $\begin{array}{c}\text { LPI } \\
\text { місце }\end{array}$ & $\begin{array}{c}\text { LPI } \\
\text { показ- } \\
\text { ник }\end{array}$ & $\begin{array}{c}\text { LPI } \\
\text { місце }\end{array}$ \\
\hline Німеччина & 4,03 & 4 & 4,12 & 1 & 4,23 & 1 & 4,20 & 1 \\
\hline Швеція & 3,85 & 13 & 3,96 & 6 & 4,20 & 3 & 4,05 & 2 \\
\hline Бельгія & 3,98 & 7 & 4,04 & 3 & 4,11 & 6 & 4,04 & 3 \\
\hline Австрія & 3,89 & 11 & 3,65 & 22 & 4,10 & 7 & 4,03 & 4 \\
\hline Японія & 3,93 & 8 & 3,91 & 10 & 3,97 & 12 & 4,03 & 5 \\
\hline Нідерланди & 4,02 & 5 & 4,05 & 2 & 4,19 & 4 & 4,02 & 6 \\
\hline Сінгапур & 4,13 & 1 & 4,00 & 5 & 4,14 & 5 & 4,00 & 7 \\
\hline Данія & 4,02 & 6 & 3,78 & 17 & 3,82 & 17 & 3,99 & 8 \\
\hline $\begin{array}{l}\text { Об'єднане } \\
\text { Королівство }\end{array}$ & 3,90 & 10 & 4,01 & 4 & 4,07 & 8 & 3,99 & 9 \\
\hline Фінляндія & 4,05 & 3 & 3,62 & 24 & 3,92 & 15 & 3,97 & 10 \\
\hline США & 3,93 & 9 & 3,92 & 9 & 3,99 & 10 & 3,89 & 14 \\
\hline Франція & 3,85 & 12 & 3,85 & 13 & 3,90 & 16 & 3,84 & 16 \\
\hline Іспанія & 3,70 & 20 & 3,72 & 18 & 3,73 & 23 & 3,83 & 17 \\
\hline Австралія & 3,73 & 18 & 3,81 & 16 & 3,79 & 19 & 3,75 & 18 \\
\hline Канада & 3,85 & 14 & 3,86 & 12 & 3,93 & 14 & 3,73 & 20 \\
\hline Україна & 2,85 & 66 & 2,98 & 61 & 2,74 & 80 & 2,83 & 66 \\
\hline $\begin{array}{l}\text { Усього } \\
\text { держав }\end{array}$ & & 155 & & 160 & & 160 & & 160 \\
\hline
\end{tabular}

Джерело: складено за [3]

Частина інвестицій на транспорт йде на розвиток Європейської системи автострад для ще більшої модернізації інфраструктури. У Німеччині відносно розвинуто всі види транспорту, але першим у перевезеннях пасажирів та вантажів $\epsilon$ автомобільний та залізничний транспорт. А така різниця у виділених інвестиціях існує через те, що залізничний транспорт уважається більш екологічним, особливо для 
перевезення великих за обсягом вантажів. Також такі суми пояснюються створенням транс'європейської швидкісної залізничної системи.

Більшість досліджень підтверджує, що історично високий рівень свого розвитку інфраструктура транспортно-логістичної сфери Німеччини досягла завдяки наявності розгалуженої залізничної колії та залізничних розв'язок, які і стали основою для перших «логістичних центрів» цієї країни.

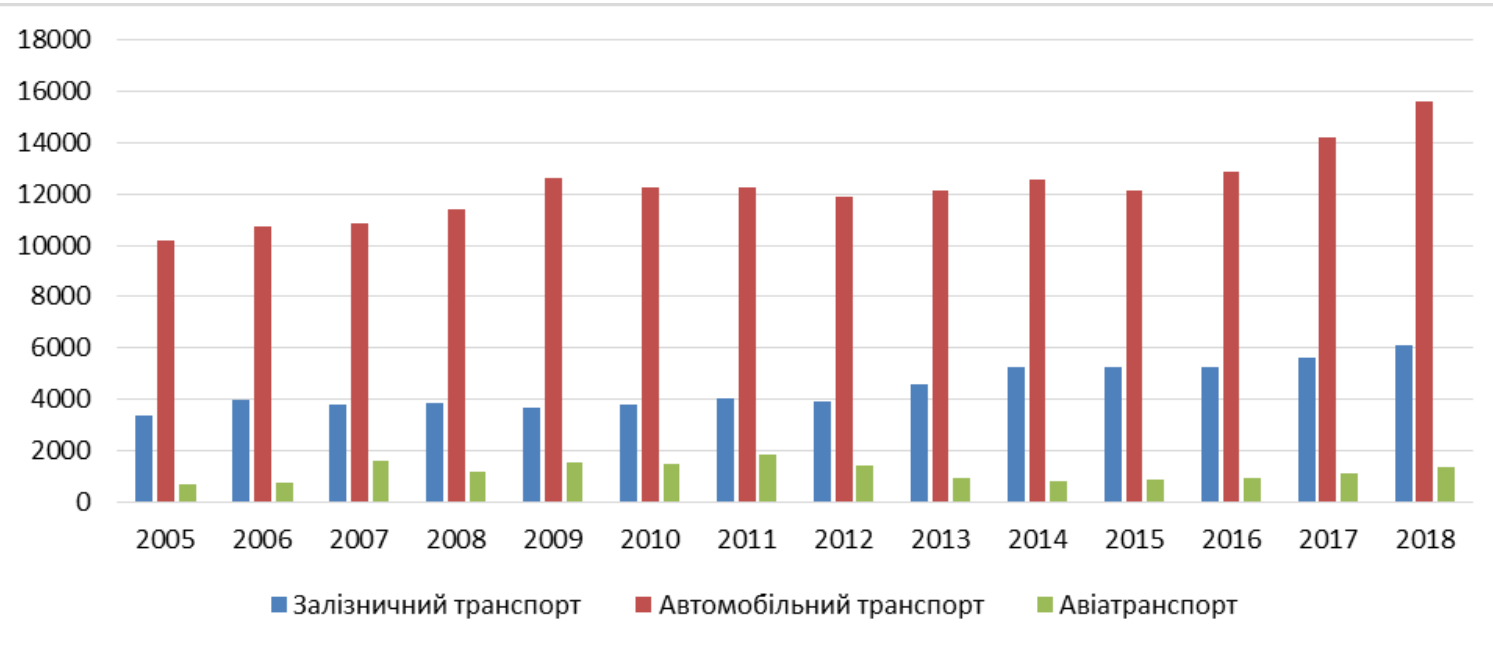

\section{Рис. 1. Обсяг державних інвестицій у транспортну інфраструктуру Німеччини, млн євро [4]}

Із позиції використання того чи іншого виду транспорту у логістичних вантажних системах кожен вид транспорту має свої переваги та недоліки, які детально наведено в табл. 2.

Розповсюдження коронавірусу призвело до дуже потужних ускладнень у всій світовій логістиці. Унаслідок цього світові міжнародні організації, такі як Міжнародний союз дорожнього транспорту (International union of road transport) та Міжнародна організація робітників траспортної сфери (International transport workers federation) звернулися до керівників усіх країн із проханням підтримати транспортні сфери в умовах COVID-19, оскільки пандемія спровокувала дисбаланс вантажних потоків, які було спровоковано тимчасовим закриттям виробництв, великими змінами попиту та загальними жорсткими обмеженнями. На думку всесвітніх організацій, керівництво країн саме на державному рівні повинне ініціювати найвищий пріоритет підтримці безперервності і міцності ланцюжків поставок.

Сьогодні до головних світових логістичних тенденцій відносять:

- суттєве зниження вантажопотоку у світовому і локальних масштабах. Серед головних причин найбільш впливові: закриття кордонів країн, масове закриття торгових точок, зростання курсу долара, ізоляція населення, зниження попиту і купівельної спроможності, а також стан 
страху і невизначеності у споживачів. Багато фабрик і заводів по всьому світу закриті на карантин - перевозити стає нічого й нікому;

- повна відсутність простих та зрозумілих правил гри в умовах карантину для представників логістичного ринку [5].

Таблиця 2

\section{Порівняльна характеристика транспорту у логістичних системах ЗЕД}

\begin{tabular}{|c|c|c|}
\hline \multirow{2}{*}{$\begin{array}{c}\text { Вид } \\
\text { транспорту } \\
\end{array}$} & \multicolumn{2}{|c|}{ Порівняльні характеристики } \\
\hline & Позитивні & Негативні \\
\hline $\begin{array}{l}\text { Автомобільни } \\
\text { й транспорт }\end{array}$ & $\begin{array}{l}\text { - автомобільний транспорт } \\
\text { повністю забезпечує доставку } \\
\text { товару від дверей до дверей; } \\
\text { - середньовисока швидкість } \\
\text { доставки товару за часом; } \\
\text {-транспорт забезпечує доставку } \\
\text { товару у тяжко доступні місця, } \\
\text { забезпечуючи маневреність }\end{array}$ & $\begin{array}{l}\text { - головний складник собівар- } \\
\text { тості перевезення - це пальне; } \\
\text { - високі фінансові затрати на } \\
\text { будівництво нових доріг; } \\
\text { - транспорт забезпечує } \\
\text { невеликі партії доставки; } \\
\text { - високі вимоги до пакування } \\
\text { товару }\end{array}$ \\
\hline $\begin{array}{l}\text { Залізничний } \\
\text { транспорт }\end{array}$ & $\begin{array}{l}\text { - дуже висока провізна } \\
\text { спроможність; } \\
\text { - регламентована регулярність } \\
\text { рейсів; } \\
\text { - погодні умови мало впливають } \\
\text { на роботу транспорту; } \\
\text { - організація навантажувальних } \\
\text { та розвантажувальних робіт на } \\
\text { високому рівні; } \\
\text { - низький складник собівартості } \\
\text { транспортних послуг }\end{array}$ & $\begin{array}{l}\text { - порівняно з іншими видами } \\
\text { транспорту невисока } \\
\text { швидкість доставки вантажу; } \\
\text { - для будівництва нової або } \\
\text { додаткової залізниці потрібні } \\
\text { великі фінансові вкладення; } \\
\text { - за використання існуючих } \\
\text { колій дуже обмежений радіус } \\
\text { використання залізницею; } \\
\text { - залізничні послуги надає } \\
\text { дуже обмежена кількість } \\
\text { перевізників }\end{array}$ \\
\hline $\begin{array}{l}\text { Трубопровідн } \\
\text { ий транспорт }\end{array}$ & $\begin{array}{l}\text { - висока спроможність щодо } \\
\text { обсягу постачання; } \\
\text { - невисокі тарифи щодо } \\
\text { транспортування }\end{array}$ & $\begin{array}{l}\text { - великі обмеження щодо } \\
\text { використання відносно виду } \\
\text { товару, який транспортується }\end{array}$ \\
\hline $\begin{array}{l}\text { Водний } \\
\text { транспорт }\end{array}$ & $\begin{array}{l}\text { - висока провізна спроможність; } \\
\text { - використання річкового } \\
\text { транспорту щодо вантажу є } \\
\text { найдешевшим видом транспорту } \\
\text { сьогодні; } \\
\text { - невисокі тарифи щодо } \\
\text { перевезення вантажу }\end{array}$ & $\begin{array}{l}\text { - транспорт не спроможний за } \\
\text { технічними характеристиками } \\
\text { швидко обслуговувати } \\
\text { замовлення; } \\
\text { - високі вимоги до пакування } \\
\text { товару для транспортування; } \\
\text { - ризик впливу зовнішніх } \\
\text { чинників, а саме погодних умов }\end{array}$ \\
\hline $\begin{array}{l}\text { Повітряний } \\
\text { транспорт }\end{array}$ & $\begin{array}{l}\text { - висока швидкість доставки } \\
\text { товару; } \\
\text { - доставки товару у тяжко } \\
\text { доступні райони за географічним } \\
\text { розташуванням; } \\
\text { - високі вимоги до зберігання } \\
\text { вантажу }\end{array}$ & $\begin{array}{l}\text { - неможливість } \\
\text { дотримуватися регулярності } \\
\text { щодо доставки товару; } \\
\text { - тарифи високого рівня; } \\
\text { - висока ймовірність впливу } \\
\text { погодних умов на доставку } \\
\text { товару }\end{array}$ \\
\hline
\end{tabular}


Якщо порівнювати втрати від спалаху COVID-19, серед транспортних галузей найбільш постраждала, за висновками експертів, саме авіаційна галузь [6] (рис. 2).

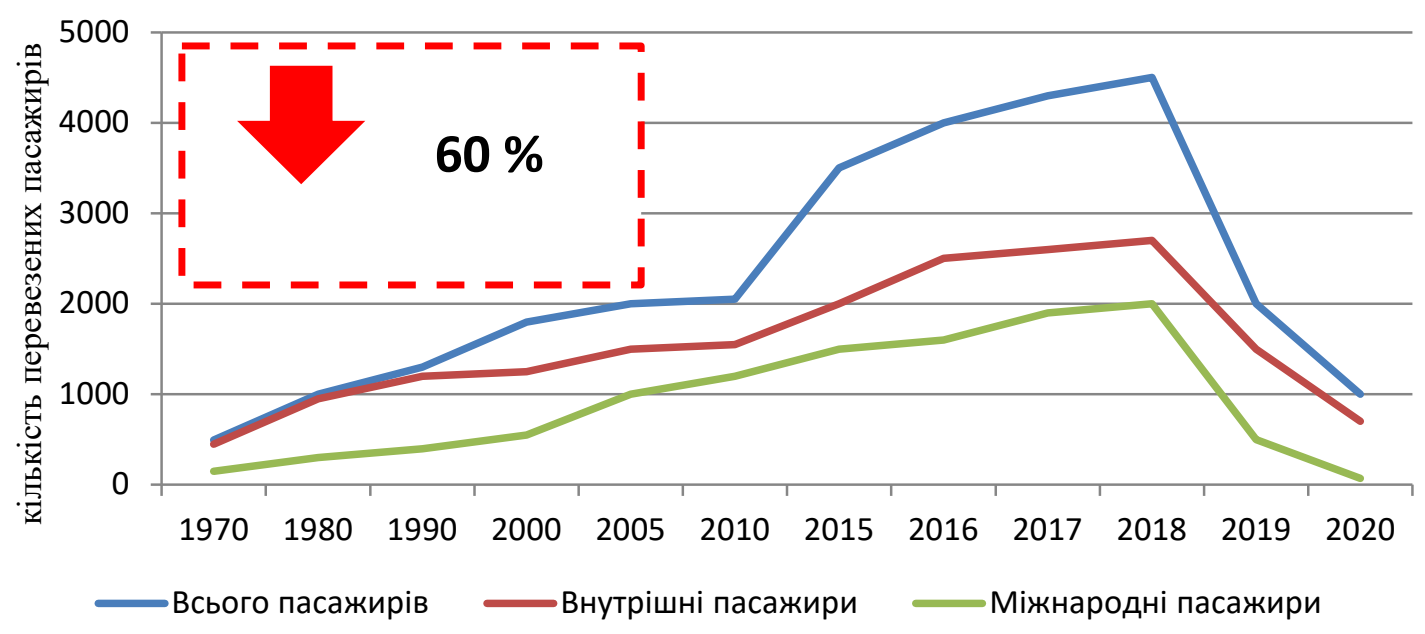

\section{Рис. 2. Динаміка світового пасажирського руху (млн осіб) [6]}

За оцінкою Міжнародної організації цивільної авіації (International Civil Aviation Organization, ICAO), за підсумками 2020 р. авіаційними компаніями перевезено 1,8 млрд пасажирів, що на 2,7 млрд менше, ніж у попередньому році (2019 р. - 4,5 млрд пасажирів).

За попередніми експертними даними, авіаційні оператори у 2021 p. отримують на 500 млрд доларів менше доходів, аніж у минулому 2020 p.

За підсумками 2020 р. аеропорти недоотримали 115 млрд дол. доходів, постачальники авіаційних послуг утратили понад 13,5 млрд дол.

Позитивним прикладом вирішення наслідків пандемії є крани Азії. Головні вантажопотоки з країн Азії до Європи потроху відновлюються, так, майже 90\% головних підприємств КНР налагодили звичайний ритм роботи і надають вантажні послуги та відправляють вантаж майже без затримок.

Розглядаючи головні тенденції автомобільного транспорту на прикладі України, слід підкреслити, що понад 10\% товару транспортується саме цим видом транспорту. Дані, наведені на рис. 3, підкреслюють позитивну динаміку росту за останні роки (до 2019 р.) щодо збільшення кількості перетину вантажними автомобілями державних кордонів України, особливо виділяється сполучення 3 Польщею (2016 р. - 600 тис авто, 2019 р. - 770 тис авто), Російською Федерацією (2016 р. - 420 тис авто, 2019 р. - 435 тис авто) та Білоруссю (2016 p. - 210 тис авто, 2019 р. - 290 тис авто).

Починаючи із середини 2019 р. і за підсумками 2020 р. позитивна тенденція значно змінюється, а саме по всіх країнах значне скорочення 
автомобільного вантажного транспорту, що зумовлено впливом пандемії COVID-19 (обмеження руху, закриття кордонів на невизначений час, значні зміни логістичних маршрутів транспортних підприємств).

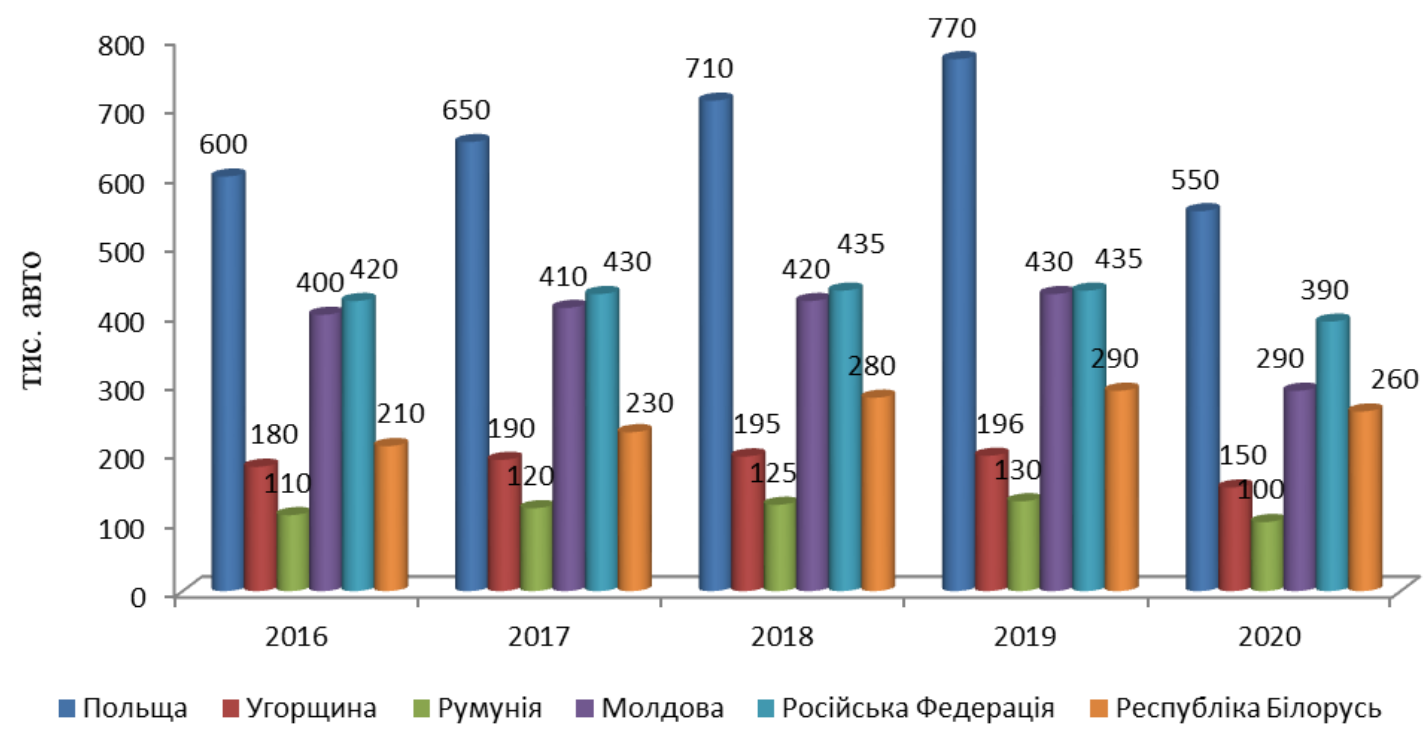

Рис. 3. Динаміка перетину автомобільного вантажного транспорту державних кордонів України, 2016-2020 pp. [7; 8]

Ускладнення, з якими примусово зіштовхнулися у 2019 р. транспортні підприємства, змусили діяти, а саме кардинально переглянути існуючі логістичні маршрути, спростити документооформлення на пунктах перетину країн, спростити процедури реєстрації та інші заходи, спрямовані на прискорення процесів транспортування та мінімізацію простоїв усіх видів транспорту.

\section{Розділ 2. Інноваційні технології логістики} як чинник подолання труднощів у період пандемії

Усе більшу роль у галузях економіки, логістики та управління ланцюгами поставок відіграють технологічні інновації. І оскільки галузь логістики активно використовує великі обсяги даних, які зберігаються окремо та в різних програмах і часто вводяться вручну, не виключено, що логістика більше виграє від упровадження нових інноваційних способів роботи.

Отже, інновація являє собою діяльність, яка спрямована на використання результатів нових ідей, нових розробок та наукових досліджень, що спричиняє появу нових конкурентоздатних та конкурентоспроможних продуктів на внутрішньому та зовнішньому ринках. 
Яскравим прикладом використання сучасних інформаційних технологій, які широко використовуються у логістичному контролінгу, $\epsilon$ безпілотні літальні апарати, котрі мають декілька напрямів у логістиці. Перший напрям, і дуже значний, - внутрішньовиробничий. Одна 3 представлених та широковживаних технологій - FlytWare. Це спроєктоване автоматизоване обладнання із завданням інвентаризаційних робіт на складах підприємств, яке зчитує QR-коди, штрих-коди, тобто здійснює контролінгову функцію незалежно від часу доби, перерв і вихідних. Дані безпілотники були розроблені німецькою компанією Linde Material Handling, яка займається виробництвом техніки для складської, сільськогосподарської та будівельної діяльності. У 2017 p. на виставці Transport Logistic у Мюнхені був представлений новітній винахід - дрон Bin:Go. Апарат має перевагу - здійснювати свою роботу поруч із людиною, не завдавши йому ніякої шкоди. Bin:Go надихнуло винахідників удосконалювати дрони, надаючи їм усе більше нових функцій $[9 ; 10]$.

Другий напрям діяльності дронів - доставка вантажів. Німецька логістична компанія DHL давно започаткувала тенденцію доставки вантажів саме безпілотними літаючими апаратами. Запуск Parcelcopter починався 3 невеликих відстаней (1 км). Пізніше переправляли медикаменти на острів Йюст (Німеччина), відстань становила 14 км. Коли дрон долітав до місця призначення, співробітники компанії його розвантажували, і вантаж доставлявся замовнику. Із роками доставка дронами вдосконалювалася, i встановили аеропорти для посадки дронів - DHL Packstation with SkyPort.

Розвиватися в інноваційному руслі логістиці допомагають безпілотні автомобілі. Сьогодні цей напрям допоможе скоротити витрати логістики приблизно вдвічі. Уже є деякі приклади застосування даних автомобілів. Так, прогресу досягли логістичні компанії Австралії, використовуючи безпілотні автомобілі на заводах. У Німеччині запустили свої безпілотні автомобілі по трасі Мюнхен - Нюрнберг, що доставляють вантажі допустимою швидкістю за певним маршрутом. Компанія PepsiCo у США придбала 110 безпілотних вантажівок Semi.

Роботизація - ще одна 3 інновацій, що використовується на логістичних підприємствах, беручи на себе всі повноваження контролінгу. Прискорене виконання робіт на різних стадіях виробництва завдяки роботизації та автоматизації допоможе підприємству зафіксувати тверді позиції в конкурентній обстановці в умовах глобалізації. Дану інновацію використовують підприємства багатьох передових країн, таких як США, Австралія, Німеччина, Франція, Нідерланди [11].

Нині від логістики очікують постійного підвищення рівнів транспортування, комунікації, складування i т. д. Одним із таких високих рівнів є програма «Остання миля», яка вважається однією 3 
найнеобхідніших i найдорожчих. Абсолютно всі компанії хочуть залишити приємне враження у клієнтів за рахунок швидкої доставки i водночас знизити транспортні витрати. Це інновація, яка допомагає контролінгу вирішувати завдання 3 раціональністю витрат, зі скороченням часу. Натомість в Україні започаткували сучасні термінали видачі замовлених товарів, котрі зберігають товари до того часу, коли замовник забере їх у зручний для нього час [12, с. 152].

У прогресивних країнах світу впроваджують у систему своїх підприємств таке нововведення, як ІоТ-технології. В узагальненому розумінні для логістичної діяльності - це технологія, яка забезпечує найбільш сприятливу побудову маршрутів, надання необхідної інформації про продукцію та клієнтів, своєчасне прибуття доставок, спостереження за станом продукції.

Використання IоТ у логістиці надає низку переваг: скорочення витрат завдяки ефективному використанню ресурсів, спостереження за транспортними засобами: їх технічним станом, місцезнаходженням, станом вантажу, зниженням пагубного впливу співробітників на діяльність компанії.

Останнім часом ІоТ-технології привели логістичну діяльність до величезного розвитку. Компанії готові вкласти в сучасні технології близько 50 млрд дол., за прогнозами експертів, до 2025 р. Тому витрати на прилади ІоТ-технологій із кожним роком зростають невпинно. На рис. 4 показано динаміку за витратами на прилади у відсотках за 2016-2020 pp.

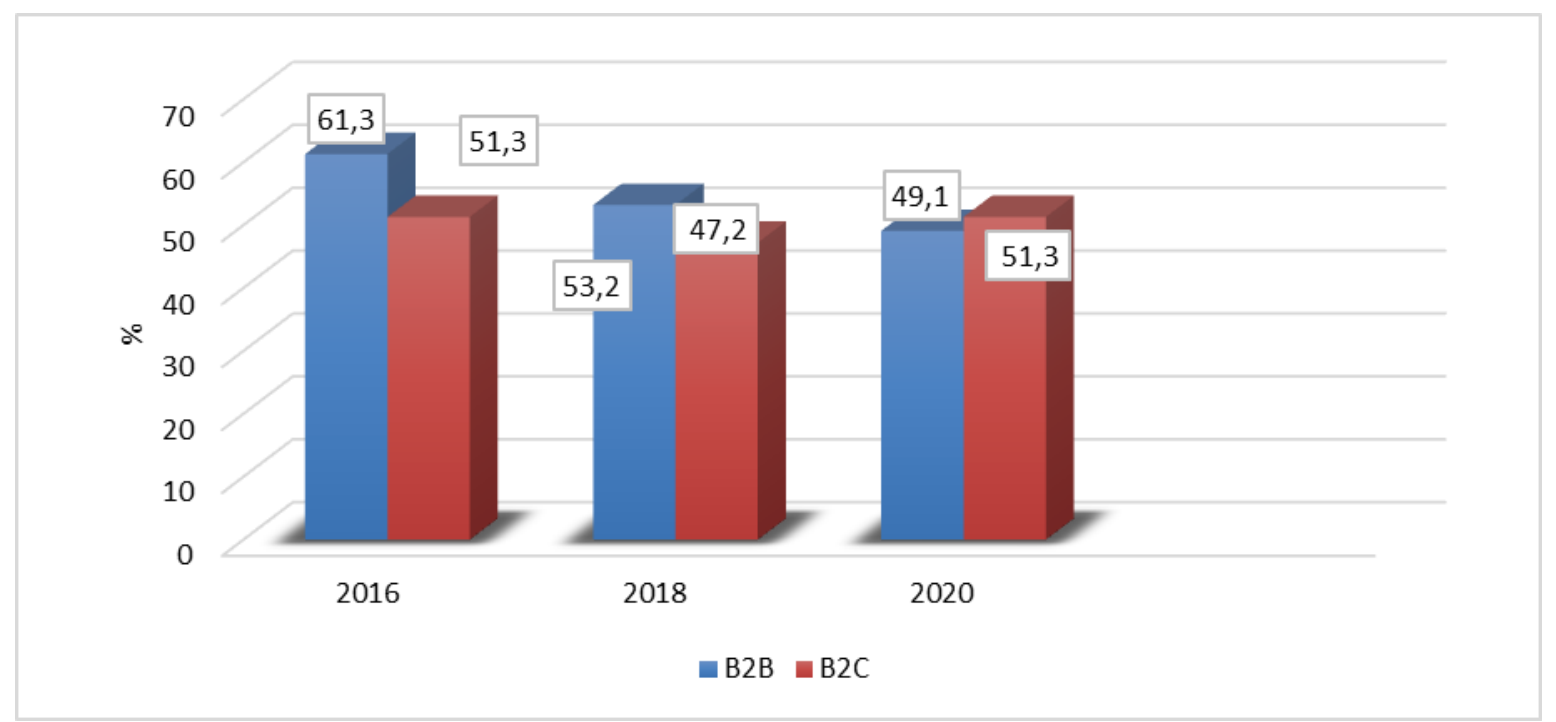

Рис. 4. Витрати на ІоТ-прилади, \%, 2016-2020 рр. [13, с. 77]

Згідно 3 рис. 4, у 2020 р. різниця між В2В та В2С невелика та становить 57 млрд дол. Витрати значно зросли у сегменті В2В станом на 2020 р. порівняно 32018 р. на 323 млрд дол., а порівняно з 2016 р. - 
на 595 млрд дол. на 2020 р. Уважається, що найкраще своє застосування IoT-технології знайшли якраз у логістиці контролінгу. Практика показує, що американська компанія AT\&T за допомогою сервісів Microsoft Azure та IBM Blockchain створила платформу, де відбувається відстеження вантажу від складу до свого користувача. Ця платформа дає змогу продивлятися стан матеріалу перед виробництвом продукції, контролювати відвантаження та прибуття до споживача. Американська компанія IBM та AOS у Колумбії застосували IоT-технології у своїй платформі для контролю координації транспортного засобу. Для цих цілей також були використані такі технології: IBM Cloud, Watson IoT, IBM Blockchain. AOS-автомобілі обладнані ІоT-датчиками для мітки RFID. Кожна мітка несе в собі певну закладену інформацію про сам вантаж, місце його знаходження, його перевізника, саме так IоTтехнології вдосконалюють логістичні процеси шляхом повного контролю [11].

Що стосується мітки RFID - це теж новітня технологія, яка стала часто використовуватися для вирішення будь-яких логістичних завдань. Логістика $\epsilon$ найбільш доцільним варіантом для впровадження $\mathrm{i}$ перспективного використання RFID-мітки, оскільки мітки володіють головними перевагами - збереження і розпізнавання інформації про об'єкти. За допомогою введення даної технології на підприємстві відбулося розвантаження співробітників шляхом автоматичних логістичних процесів. За допомогою тегів із легкістю можна помітити нестачу у вантажі й оперативно знайти його. Багато країн світу усвідомили всю значимість і ефективність RFID-міток, використовуючи їх на багатьох підприємствах різних напрямів. Компанія Marks\&Spencer у Великобританії застосовує цю технологію для доставки найсвіжіших продуктів. Сучасна логістична система використовує мітки для понад 12 млн піддонів, де зчитується інформація: дата упаковки продуктів, температура транспортування, рекомендований час доставки, виробники та ін. Американське підприємство Mission Foods почало використовувати пластикові контейнери з RFID-технологією, оскільки компанія щорічно витрачала на одноразові коробки понад 6 млн дол. США, які після прибуття мали деформацію і виявлялася їх нестача. Таким чином, завдяки використанню міток компанія перестала нести величезні збитки [14].

Ще одним із проявів масштабних змін у логістиці стали інформаційні системи, які значно полегшують виконання логістичних процесів, сприяючи їхній контролінговій діяльності. Логістичні системи нині виконують велику кількість функцій, найбільш поширені інформаційні системи у логістиці: СТС (Швейцарія) - оповіщення перевізників, експедиторів; Espace Cat (Франція) - інформування клієнта про габарити його вантажу; GPS (США) - супутникова система для виявлення місця розташування транспорту; Gonrand (Франція) - пошук і збір інформації 
про фактичну кількість товару; Videotrans (Бельгія) - підтримка транспортних компаній за допомогою інформації; ISCIS (США) забезпечення логістичного каналу завдяки інформації [15].

Також зараз особо популярними $є$ автоматичні рішення, найбільш популярні підвиди якого, звісно ж, коштують багато грошей i $\epsilon$ доступними тільки для крупних гравців, але вони значно зменшують витрати у довгостроковій перспективі.

Warehouse Management Systems, або система управління складом, - це спеціальна програма автоматизації роботи складу. Даний софт фіксує усі зміни в інвентарі та дає змогу планувати його заздалегідь. Також дуже важливою метою використання Warehouse Management Systems $\epsilon$ фіксація строків зберігання, що вкрай важливо для товарів, що швидко псуються [16].

Transport Management Systems, або система управління транспортом, це спеціальна логістична платформа для оптимізації перевозок товарів різноманітними видами транспорту. Програма досліджує усі переміщення, норми проходження, технічні моменти, а також сама розробляє плани щодо оптимізації маршруту [17].

Order Management Systems, або система управління замовленнями, це спеціальний вид програм для автоматичного прийняття замовлень. Головна мета даної програми - налаштувати роботу в компанії так, щоб iii обіг не залежав від кількості працівників відділу продаж. Дають можливість надання дійсно якісного обслуговування та прискорення усіх логістичних ланок ланцюгів постачання [18].

Supply Chain Execution - це комплексне рішення всіх поставлених вище питань. Ця програма може включати в себе і роботу з клієнтами, і автоматизацію складу. Ці інструменти коштують чимало (наприклад, софт від компанії Smart коштує від 1000 доларів на місяць для маленької компанії і від 10 тис - для порівняно невеликої), але можуть замінити велику кількість працівників [19].

Учені та економісти шукають цікавіші способи вирішення проблеми, навіть якщо вони більш складні, головне - їх універсальність. Для цього ще із середини минулого століття Дж. Форестер вирішував задачі імітаційного моделювання. Дуже незвичною та перспективною є модель із використанням нечіткої логіки для формування правил замовлень та заповнення інвентаря. Ідея моделі полягає у тому, що кожне замовлення та коливання попиту можна задати за допомогою нечітких правил, тобто багатофакторної моделі з імовірностями.

Блискучим прикладом розвитку логістичного сервісу в Україні $\epsilon$ «Нова Пошта». Компанія займає лідируючі позиції на логістичному ринку і спрямована на перспективне майбутнє, використовуючи у своїй діяльності нові технології з метою відповідності всесвітнім нормам і отримання кращого міжнародного досвіду. Постійна робота над поліпшенням сервісу призводить до залучення клієнтів, до їх 
зацікавленості в послугах компанії, а також неймовірний ріст показників за останні роки забезпечує стійке положення на ринку логістичних послуг.

Під впливом діючих обмежень в умовах пандемії у 2019 р. «Нова Пошта» зробила неймовірний стрибок із відкриття нових відділень, тим самим виконавши свій стратегічний план. Українських відділень стало більше на 55\% за рахунок залучення сіл та невеликих міст (рис. 5).

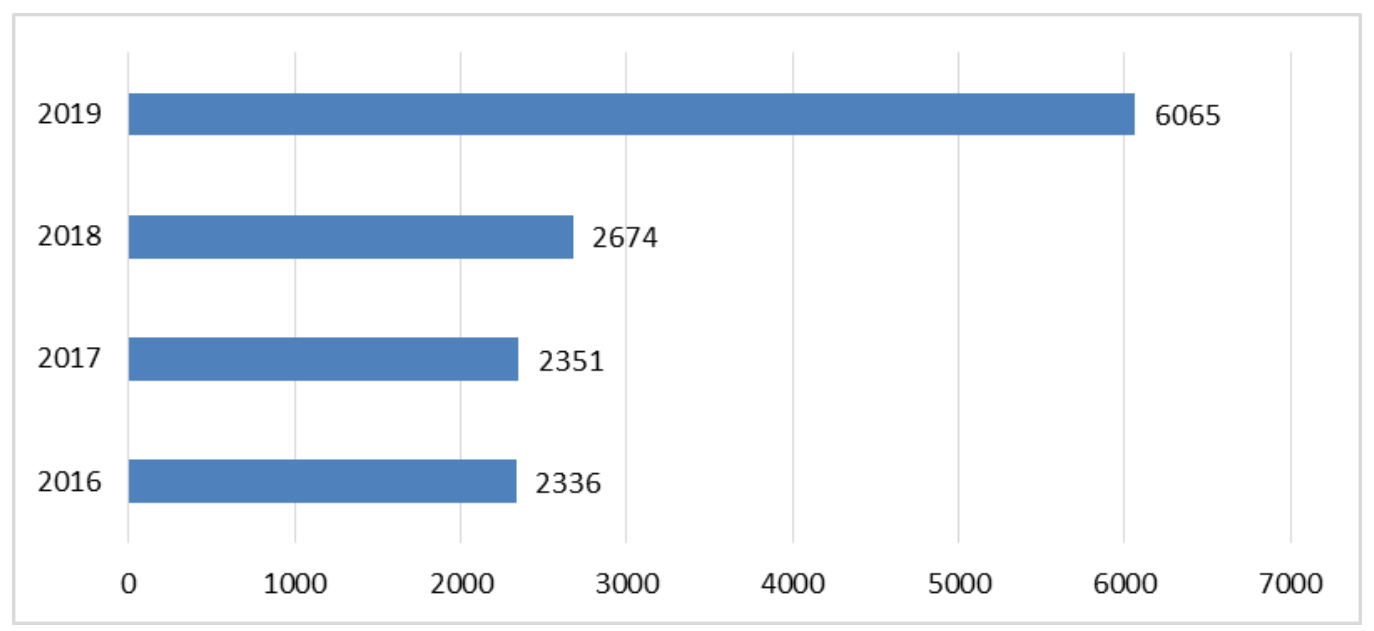

Рис. 5. Кількість відділень «Нової Пошти», 2016-2019 рр. [19]

Сьогодні саме «Нова Пошта» є прикладом боротьби з COVID-19. Ситуація з пандемією максимально підвищила значимість послуг, що надаються компанією в Україні. «Нова Пошта» повністю взяла на себе величезну кількість логістичних послуг. Тільки за перше півріччя 2020 р. компанія здійснила 130 млн відправлень, що в 2,4 рази більше, ніж за той самий період попереднього року; також у два рази зросли міжнародні відправлення. У період пандемії спостерігається тенденція зростання онлайн-покупок, тому всі сили компанії спрямовані на швидкість і надійність доставки. У діяльність компанії з початку карантину була введена нова послуга - доставка лікарських препаратів. Так, за чотири місяці було здійснено 90 тис доставок саме медикаментів.

Компанія не зупинилася на нововведеннях у своїй діяльності під час карантину і встановила понад 400 почтоматів в Україні. Ця послуга гарантує оплату та отримання своєї посилки без контактування 3 людьми. Також «Нова Пошта» впровадила нову систему оплати шляхом списання грошей із картки, прив'язаної до додатку «Нова Пошта», забезпечуючи швидкість та зручність оплати.

Оскільки в умовах пандемії значно збільшився попит на послуги «Нової пошти», компанія почала використовувати вантажні робовізки, які переміщують вантаж у зону навантаження вагою до 1200 кг, тягнучи 
за собою, та до 400 кг - на собі. Така технологія створює умови для продуктивності та швидкості логістичних процесів.

Наведені системи використовуються у логістичному контролінгу для створення могутньої системи логістики, підтримуючи ії на кожному кроці виконання процесів. Зараз неможливо не оцінити потужний вплив штучного інтелекту, інформаційних, інноваційних технологій, нових систем на логістичну діяльність та логістичний контролінг. Вони функціонують для спрощення та зручності, приносячи компаніям найменші витрати та задоволених клієнтів.

\section{Висновки}

Пандемія залишила свій відбиток на логістичній системі кожної країни, тим самим погіршила стан глобальної логістики. Усі галузі посвоєму відчули вплив коронакризи, тепер завдання полягає у пошуку рішень швидкого повернення в колишне русло. Оскільки навколишне середовище завжди неодмінно мало вплив на логістику, а нині цей вплив посилився в рази, то виникає необхідність у швидкій реакції на перешкоди, що з'являються у здійсненні діяльності, оперативності і послідовності кроків за досягнення стратегічних цілей логістичних підприємств у вигляді трансформації інформаційної бази. Оновленого логістичного поштовху на підприємствах можна домогтися шляхом уведення інформаційних, інноваційних технологій, які зосередяться на процесах оптимізації, прискорення, поновлення логістичних операцій.

Транспортна логістика не встигла оговтатися від наслідків пандемії, як відбулася подія, котра показала важливість налагодження мультимодальних перевезень і швидкість реагування в подібних ситуаціях. Ever Given - це контейнеровоз, який прямував із Китаю до Нідерландів, заблокував Суецький канал та завдав серйозних проблем для світової логістики. За пронозами експертів, година простою світовій торгівлі обходилася в 400 млн доларів. Так, наприклад, через цю ситуацію контейнери, які прямували з Китаю до Європи, виросли в чотири рази. Ця ситуація - урок для компаній щодо вдосконалення мультимодальних перевезень.

Також слід виділити один із напрямів, який «виграв» у ситуації 3 обмеженнями щодо пандемії, - складська логістика. Прибутковість складської логістики, за підрахунками експертів, збільшилася майже в два рази. Це зумовлено величезним попитом на складські приміщення, оскільки після введення перших обмежень по всьому світу в десятки разів стрибнули закупки готових виробів, матеріалів та напівфабрикатів. Такі тенденції пояснюються нерозумінням майбутніх обмежень та загрозою введення жорстких карантинних заходів на невизначені терміни. Усе це спонукає логістичну галузь розуміти нестабільність та працювати над альтернативними логістичними ланцюгами. 


\section{Список використаних джерел:}

1. Roekel van W.S. Improving international logistics performance measurement. 2017. URL: http://resolver.tudelft.nl/uuid:bbec46b9-c6bc-475f-ba61-2f3404bc7178

2. Assessment of Perspective Development of Transport and Logistics Systems at Macro and Micro Level under the Conditions of Industry 4.0 Integration / O. Maiboroda et al. International journal of computer science and network security. 2021. Vol. 21. № 3. P. 235-244. URL: https://doi.org/10.22937/IJCSNS.2021.21.3.32

3. Статистичні дані про інвестування Німеччини у повітряний транспорт. URL: https://www.statista.com/statistics/439425/investment-in-airport-infrastructure-in-germany

4. Логистические тренды 2020-2021 годов. URL: https://www.retail.ru/articles/ logisticheskie-trendy-2020-2021-goda-vliyanie-pandemii-covid-19-na-perevozki/

5. World passenger traffic evolution. URL: https://dsl-ua.com/ua/2021/02/04/2020pidsumki-dlya-aviatsiynoyi-galuzi/

6. Державна служба статистики України. URL: http://www.ukrstat.gov.ua

7. Мировой атлас данных. URL: https://knoema.ru/atlas

8. The Word Bank. URL: https://lpi.worldbank.org/international/global

9. Сферы применения беспилотных летательных аппаратов. URL: https://pioneer-doc.readthedocs.io/ru/master/database/base-module/sphere/sphere.html

10. Пученков В. Использование дронов на складах. Инноващии. 2017. № 6. С. 16-17.

11. Середницька Л.П., Волинець В.В. Інноваційні технології в логістичній системі. Економіка і суспільство. 2018. № 19. С. 617-621.

12. Ільченко Н.Б., Котова М.В. Остання миля для електронної торгівлі: виклики, переваги та майбутнє. Бізнес Інформ. 2020. № 3. С. 149-155.

13. Гринчак Н.А. Аналіз впливу технологій Інтернету речей на розвиток ринку транспортно-логістичних послуг. Науковий вісник Наџіональної академії статистики, обліку та аудиту. 2019. № 4. С. 74-82.

14. RFID enables Mission Foods to improve traceability, reduce costs. URL: https://www.reliableplant.com/Read/24043/RFID-Mission-Foods-traceability

15. Кривов'язюк І.В., Кулик Ю.М. Проблеми застосування інформаційних технологій в управлінні логістичною системою підприємства. Актуальні проблеми економіки. 2013. № 12. С. 29-38.

16. Про Warehouse Management Systems. URL: https://searcherp.techtarget.com/ definition/warehouse-management-system-WMS

17. Про Transport Management Systems. URL: https://www.oracle.com/scm/what-istransportation-management-system

18. Про Order Management Systems. URL: https://www.nchannel.com/blog/top-5order-management-systems

19. Нова Пошта. URL: https://novaposhta.ua

\section{References:}

1. Roekel van W. S. (2017) Improving international logistics performance measurement. URL: http://resolver.tudelft.nl/uuid:bbec46b9-c6bc-475f-ba61-2f3404bc7178

2. O. Maiboroda, L. Bezuhla, A. Gukaliuk, V. Shymanska, T. Momont, T. Ilchenko. (2021) Assessment of Perspective Development of Transport and Logistics Systems at Macro and Micro Level under the Conditions of Industry 4.0 Integration. International journal of computer science and network security, vol. 21, no. 3, pp. 235-244. DOI: https://doi.org/10.22937/IJCSNS.2021.21.3.32

3. The Word Bank. URL: https://pi.worldbank.org/international/global

4. Statystychni dani pro investuvannya Nimechchyny u povitryanyy transport [Statistics of German investment in air transport]. URL: https://www.statista.com/statistics/439425/ investment-in-airport-infrastructure-in-germany 
5. Logisticheckiy trendy 2020-2021 [Logistics trends of 2020-2021]. URL: https://www.retail.ru/articles/logisticheskie-trendy-2020-2021-goda-vliyanie-pandemiicovid-19-na-perevozki/

6. World passenger traffic evolution. URL: https://dsl-ua.com/ua/2021/02/04/2020pidsumki-dlya-aviatsiynoyi-galuzi/

7. Derzhavna sluzhba statystyky Ukrayiny [State Statistics Service of Ukraine]. URL: http://www.ukrstat.gov.ua

8. Mirovoy atlas dannykh [World Atlas]. URL: https://knoema.ru/atlas

9. Sfery primeneniya bespilotnykh letatel'nykh apparatov [Spheres of application of unmanned aerial vehicles]. URL: https://pioneer-doc.readthedocs.io/ru/master/database/ base-module/sphere/sphere.html

10. Puchenkov V. (2017) Ispol'zovaniye dronov na skladakh [Use of drones in warehouses]. Innovatsii, no. 6, pp. 16-17.

11. Serednyts'ka L.P., Volynets' V.V. (2018) Innovatsiyni tekhnolohiyi v lohistychniy systemi [Innovative technologies in the logistics system]. Ekonomika i suspil'stvo, no. 19, pp. 617-621.

12 Ilchenko N.B., Kotova M.V. (2020) Ostannya mylya dlya elektronnoyi torhivli: vyklyky, perevahy ta maybutnye [The last mile for e-commerce: challenges, benefits and future]. Biznes Inform, no. 3, pp. 149-155.

13. Hrynchak N.A. (2019) Analiz vplyvu tekhnolohiy Internetu rechey na rozvytok rynku transportno-lohistychnykh posluh [Analysis of the impact of Internet of Things technologies on the development of the market of transport and logistics services]. Naukovyy visnyk Natsional'noyi akademiyi statystyky, obliku ta audytu, no. 4, pp. 74-82.

14. RFID enables Mission Foods to improve traceability, reduce costs. URL: https://www.reliableplant.com/Read/24043/RFID-Mission-Foods-traceability

15. Kryvov yazyuk I.V., Kulyk Yu.M. (2013) Problemy zastosuvannya informatsiynykh tekhnolohiy $\mathrm{v}$ upravlinni lohistychnoyu systemoyu pidpryyemstva. [Problems of application of information technologies in management of logistic system of the enterprise]. Aktual'ni problemy ekonomiky, no. 12, pp. 29-38.

16. Warehouse Management Systems. URL: https://searcherp.techtarget.com/definition/ warehouse-management-system-WMS

17.Transport Management Systems URL: https://www.oracle.com/scm/what-istransportation-management-system

18. Order Management Systems URL: https://www.nchannel.com/blog/top-5-ordermanagement-systems

19. Nova Poshta [New Post]. URL: https://novaposhta.ua 